Mavi Atlas, 9(2)2021: 157-166

Makale Geliș | Received: 22.09.2021

Makale Kabul | Accepted: 19.10.2021

DOI: 10.18795/gumusmaviatlas.999116

Hakkı YAPICI

Doç. Dr. Assoc. Prof. Dr.

Gümüşhane Üniversitesi, Edebiyat Fakültesi, Tarih Bölümü, Gümüşhane -TÜRKIYYE

Gümüşhane University, Faculty of Letters, Department of History, Gümüşhane-TURKEY

ORCID: 0000-0001-5381-830

hyapici@gumushane.edu.tr

\title{
Tarih Öğretmeni Adaylarının Sözlü İletişim Becerileri Üzerine Bir Araştırma ${ }^{1}$
}

$\ddot{\mathrm{O} z}$

Sözlü iletişim, bireysel ve toplumsal anlamda oldukça önemlidir. Söz konusu öğretmenler olduğunda önemi bir kat daha artar. Eğitim ve öğretim sisteminin en önemli unsurlarından kabul edilen öğretmenlerin sahip olması gereken özelliklerinden birisi de sözlü iletişim becerileridir. Çünkü öğrenci, öğretmenin "şunların yapılması gerekir." dediklerinden çok yaptı̆̆1 davranışlardan etkilenir. Bu nedenle öğretmenlerin her şeyden önce kendi ifade tarzıyla öğrencilere örnek olması gerekir. Bu çalışmada tarih bölümünde okuyan ve ileride tarih öğretmeni olabilecek öğrencilerin sözlü iletişim yeterlilik düzeylerinin sınıf ve cinsiyet değişkenlerine göre değerlendirmek amaçlanmıştır. Çalışmanın örneklem grubunu Gümüşhane Üniversitesi Edebiyat Fakültesi Tarih Bölümü’nde öğrenimlerini sürdüren 46 2. sınıf öğrencisi ve 40 4. sınıf öğrencisi oluşturmuştur. Çalışmanın verilerini toplamak amaciyla Maden'in (2010) geliştirdiği "Sözlü İletişim Yeterlikleri Gözlem Formu (SIYYGF)" kullanılmıştır. Araştırma sonucunda tarih öğretmeni adaylarının sözlü iletişim becerilerine kısmen sahip oldukları söylenebilir. Bu sonuca göre öğretmen adayları sözlü iletişimde yeterli görünse de sözlü iletişim becerilerinin daha güçlü olması için iyi bir sözcük hazinesine sahip olmalıdırlar. Yani öğretmen adaylarının aynı zaman da iyi birer okur olması gerekir. Bu konuda öğrenciler mutlaka teşvik edilmelidir. Araştırmadan elde edilen diğer önemli sonuç ise, 2. sınıf öğrencilerinin sözlü iletişim becerisinin 4. sınıf öğrencilerine göre daha düşük seviyede olmasıdır. Bu sonucun çıkmasında 2. sınıf öğrencilerinin henüz öğretmenlik mesleğine yönelik uygulamalara (okul deneyimi ve öğretmenlik uygulaması gibi.) katılmamış olmalarının etkili olduğu söylenebilir.

Anahtar Kelimeler: Tarih Öğretimi, Tarih Öğretmeni Adayı, İletişim, Sözlü İletişim.

\section{A Research on Verbal Communication Skills of History Teacher Candidates}

\begin{abstract}
Verbal communication is very important in individual and social sense. Especially when it comes to teachers, its importance increases even more. Teachers are one of the most important elements of education and training. One of the significant features, which teachers, who are one of the most important elements of education and teaching, should have, is verbal communication skills, because the student is influenced more by his or her teacher's actions than by what s/he says is "to be done". Therefore, teachers, firstly, should set an example for students with their own power of expression. In this study, it is aimed to evaluate the verbal communication proficiency levels of the students who study in the department of History and who may become a history teacher in the future in terms of the class and gender variables. The sample group of the study consisted of 46 2nd grade students and 40 4th grade students studying at the History Department of the Faculty of Letters of Gümüşane University. The "Verbal Communication Competencies Observation Form (VCCOF)" developed by Maden (2010) has been used to collect the data of the study. As a result of the research, it can be said that history teacher candidates partially have verbal communication skills. According to this result, although the teacher candidates seem sufficient in verbal communication, they should have a good vocabulary in order to have stronger verbal communication skills. In other words, teacher candidates should also be good readers. In this regard students should be encouraged. Another important result obtained from the research is that the verbal communication skills of the 2nd grade students are lower than the 4th grade students' skills. It can be said that the fact that the 2 nd grade students have not yet participated in practices related to the teaching profession (such as school experience and teaching practice) has been effective in this result.
\end{abstract}

Keywords: History teaching, History Teacher Candidate, Communication, Verbal communication.

\footnotetext{
${ }^{1}$ Gümüşhane Üniversitesi Bilimsel Araştırma ve Yayın Etik Kurulu 09.06.2021 tarih ve 2021/4 sayılı kararıyla bu araștırmanın etik ilkelere uygun olduğu onaylanmıștır.
} 


\section{Giriş}

Sosyal yaşamda iletişim kurma ihtiyacı hayatımızın her anını kapsamaktadır. İnsanların dış dünyayı kavraması yoluyla yorumlaması ve anlamlandırması iletişim olarak tanımlanmaktadır. Demirel (2001, s. 14) iletişimi; "İletilmek istenen duygunun, düşüncelerin duyu organlarını kullanarak telefon, televizyon, radyo, internet vb. kitle iletissim araçlanından faydalanarak bir kişiden diğer bir kişiye aktarılması" diye ifade edilmektedir. Bu tanımlamaya ek olarak bireylerin içten gelen duygularının ve düşüncelerinin kelimeler ya da beden dili aracıllğıyla dışa yansıtılmasıdır. İletişim bir davranış biçimi olduğu kadar aynı zamanda da hayat boyu devam eden bir süreçtir. Anlatılmak istenen duygu ve düşünceler zihinsel, duygusal, bedensel faaliyetler aracıllğıyla etkileşimi gerçekleştirirler (Baki, 2019, s. 19).

İletişim süresince birey kendi özgürlüğ̈̈nü ve haklarını koruduğu gibi diğer insanların özgürlüklerine ve haklarına da aynı hassasiyeti gösterir (Fidan \& Küçükali, 2014, s. 318). İletişimin etkili olması, hedefine ulaşması için tarafların istekli olması, konuyla ilgili kazanımları, bakış açısı büyük önem arz eder. Bu zaman diliminde kişi iletişim sayesinde günlük yaşamını düzenleme firsatını yakalar. $\mathrm{Bu}$ perspektiften bakıldığında iletişimin bireyin kaliteli ve verimli bir hayat sürdürebilmesi için temel şart olmaktan ziyade birey için gerekli bir zaman olduğu denilebilir. Öyle ki insanlar arasındaki iletişim süreci devamlı olarak sosyal yaşamda sıcaklığını korumakta ve tartışma konusu olmaktadır. Günlük sosyal yaşamımızda son derece önemli olan iletişim, birey yaşantılarının tüm karmaşalığından ve karışıklı̆̆ından beslenen etkin, faal ve belirsiz bir dönemdir (Ocak \& Karakuş, 2015, s. 155). Sözlü iletişim becerileri yönünden faal olan bireylerin sosyal yaşamda başarılı ve öz güven duygularının da mükemmel olduğu rahatlıkla söylenebilir.

Eğitim öğretim sürecinin en önemli anahtarlarından biri de iletişimdir (Karadă̆ \& Çalışkan, 2009, p. 125). Eğitim öğretim sürecinin her safhasında uygun öğretim metotlarının planlanmasında, materyallerin doğru tespitinde ayrıca gelecek nesillerin yetiştirilmesinde önemli görev üstlenen öğretmenlerin yetiştirilmesinde etkili iletişim kurma vazgeçilmez bir önem arz eder (Maden, 2010, s. 147). Baş döndürücü bir hızla ilerleyen teknolojik gelişmeler, bilim alanındaki önemli kazanımlar, sosyal yaşamda insan ilişkilerini, toplumsal değerleri, tüm eğitim öğretim aktivitelerini, öğretmenlik anlayışını, öğretmen-öğrenci-veli ilişkilerini derinden etkilemekte, eğitimcileri meslek hayatının her safhasında uzman bir öğretmen olmaya mecbur bırakmaktadır. Öyle ki eğitim öğretim sanatını icra eden öğretmenlerin doğru ve etkili öğretme yöntemlerini belirlemesi, sınıf içi ve sınıf dışı öğrencilerle etkin bir iletişim kurmayı başarması, öğrencilerin duygu düşünce ve kaygılarını anlaması ve onlara uygun hâl ve hareket içinde kendi otokontrolünü sağlayabilmesi oldukça önemlidir (Küçüksüleymanoğlu \& Çetinkaya, 2014, s. 329). Sosyal yaşantımızın her safhasında var olan iletişim, bu bağlamda eğitim öğretim hayatının çok önemli bir parçasıdır (Yılmaz vd., 2010, s. 144). Sağlıklı ve etkili bir eğitim öğretim faaliyetinin sürdürülebilmesi için öncelikle öğrencilerin bireysel özelliklerinin doğru tespit edilmesine dikkat edilmelidir (Habacı vd., 2013, s. 1645). Her bir öğrenciye ait potansiyel gücün ortaya çıkarılması, eğitim öğretim sürecinin temel unsurlarından sayılan, okul-öğretmen-öğrenci-veli-çevre ilişkilerinin sağlam olması gerekmektedir (Engin \& Aydın, 2010, s. 5). Zira eğitim öğretim aktivitelerinin üstün başarıya ulaşabilmesi ve kişisel farlılıkların ortaya çıkarılması için ön koşul eğitim sisteminde merkez güç kabul edilen öğretmenlerin öğrencileriyle doğru, etkili kaliteli bir etkileşim ve iletişim kurabilmesi büyük ehemmiyet taşımaktadır. Çünkü öğretmen ancak sağlıklı ve etkili iletişim sayesinde öğrencilerine faydalı olarak örnek bir rol üstlenmiş olur (Erdem, 2016, s. 301).

Etkili iletişim kurmada konuşma becerisinin rolü oldukça önemlidir. Konuşma, sosyal yaşantımızın her anında yer alan, bir mesele hakkında duygu ve hislerimizin, yaşadığımız olayların, düşüncelerimizin, deneyimlerimizin kısaca hayata dair her şeyimizin sözlü bir şekilde ifade edilmesine denir. Başka bir ifadeyle konuşma, bireylerin belirli bir dil sayesinde sesli olarak 
Yapıcı, H. (2021). Tarih öğretmeni adaylarının sözlü iletişim becerileri üzerine bir araştırma,

iletişime geçme aktivitesidir (Calp, 2005, s. 41). Sosyal hayatımızın her aşamasında ehemmiyetli bir durum arz eden konuşma yeteneğinin dört aşaması aşağıda sıralanmaktadır:

1. Konuşma tekniğinin fiziki özelliği: Konuşma aktivitesi sesin boş bir alanda hareketi ile meydana gelen bir hadisedir.

2. Konuşma tekniğinin fizyolojik yapısı: Konuşma, insan organizmasında bulunan ağızdan başlayarak küçük ve büyük dil, diş, dudak ve damak, ses telleri, sinir sistem yapısı, akciğer gibi organların belli bir düzen ve uyum içerisinde çalışmasıdır.

3. Konuşma aktivitesinin psikolojik özelliği: Bireyler, anlam yapısına göre kavramların kendi düşünceleriyle ilgili değil, o yapılara ait tecrübeleri hakkında fikir yürütmesidir.

4. Konuşma tekniğinin sosyal özelliği: Konuşma aktivitesi sosyal yaşamın çok önemli bir boyutudur. İnsanoğlu var olduğu andan itibaren çevresiyle iletişim kurma ihtiyacını derinden hissetmiştir. Konuşma özelliği insanlar arası iletişim ve etkileşiminin sesli olarak vuku bulmasıdır (Temizyürek vd., 2007, s. 247-248).

Etkili ve güzel konuşmada önemli olan diğer bir konu bireyin sahip olduğu sözcük hazinesidir. Öyle ki kişinin sözcük dağarcı̆̆ı kifayetsiz ise konuşma esnasında karşısındakine anlatmak istediği düşünceyi doğru bir şekilde aktaramaz. Konuşma esnasında sik sik tekrara düşer. Bu durum konuşan ve dinleyen arasındaki iletişimi olumsuz etkiler (Eyüp, 2013, s. 97).

Günlük sosyal yaşamda etkili iletişim becerilerine sahip olan bireylerin öz güven duygularının da gelişmiş olduğu açıkça görülmektedir. Birey sahip olduğu öz güven duygusu sayesinde hayatın her anında kendi kendine yeter bir duruma sahip olmasının yanı sıra, karşılaştı̆̆ problemler karşısında umutsuzluğa düşmeden çözüm üretebilen, toplumda sayılan sevilen, hoşsohbet kişi olarak aranan bir kişi olma özelliğini de taşır. Ayrıca öz güven duygusu gelişmiş bireylerin hedeflerine ulaşmalarında zorluk çekmedikleri bir gerçektir. Sosyal çevresiyle etkili iletissim kuran, olumsuzlukları bastırarak olumlu bir ortam oluşturan kişiler kendileri hayattan zevk aldıkları gibi arkadaşlarını da mutlu ederler (Saraç, 2006, s. 109). Etkili bir sözlü iletissim yalnızca birey açısından değil aynı zamanda toplumun huzur ve güveni için de büyük önem taşır. Öyle ki; toplumların demokratik bir yapıya kavuşmasında toplumu meydana getiren her ferdin yeterli iletişim becerisine sahip olmaları yadsınmaz bir gerçektir. Zira iletişim becerileri gelişmiş bireylerden oluşan toplumlar birbirlerini daha iyi anlayabilir, sorunları anlaşarak çözebilir, güven ve huzur ortamının var olduğu bir pozisyona sahip olabilirler. Aksine iletişim becerileri gelişmemiş bireylerden oluşan toplumlarda kaba güç, zorbalık, anlaşmazlık, çatışma hâkim olduğu gibi güven ve huzur ortamı da oluşmaz (Sever, 1998, s. 53).

\section{Araştırmanın Amacı}

Literatürde tarih öğretmeni adaylarının sözlü iletişim becerilerini ortaya koyan bir çalışmanın olmadığı görülmüştür. Ancak yapılan literatür araştırmalarında farklı branşlarda sözlü iletişim becerilerinin tespitine yönelik çalışmalar yer almaktadır. Araştırmamızda tarih öğretmenleri adayları için çok önemli farklılık olan sözlü iletişim becerilerinin (cinsiyet-kaçıncı sınıfta okuduğu) değişkenleri dikkate alınarak analizler yapılmıştır. Elde edilen bulgulardan hareketle tarih öğretmeni adaylarının sözlü iletişim becerilerini en üst seviyede kullanmaları amaçlanmaktadır.

\section{Yöntem}

Tarih öğretmeni adaylarının sözlü iletişim becerilerinin tespitine yönelik bu araştırmada yöntem olarak tarama listesi, fiziksel ve bilişsel özellikler içeren anket uygulaması yapılmıştır. Ayrıca araştırma içinde yer alan çalışma grubu ve verilerin bir araya getirilmesi, gerekli analizlerin yapılması da yer almaktadır.

Problem Cümleleri: Araştırmamızda aşağıda yer alan problem cümlelerine cevaplar aranmaktadır. 
Yapıc1, H. (2021). Tarih öğretmeni adaylarının sözlü iletişim becerileri üzerine bir araştırma,

Mavi Atlas, 9(2), 157-166

1. Tarih öğretmeni adaylarının sözlü iletissim yeterlik düzeyleri nasıldır?

2. Tarih öğretmeni adaylarının sözlü iletişim yeterlik düzeyleri cinsiyete göre farklılık göstermekte midir?

3. Tarih öğretmeni adaylarının sözlü iletişim yeterlik düzeyleri sınıf durumuna göre farklılık göstermekte midir?

\section{Evren ve Örneklem}

Çalışma grubumuzu Gümüşhane Üniversitesi Edebiyat Fakültesi, Tarih Bölümü ikinci ve dördüncü sınıf öğrencileri oluşturmaktadır. İkinci sınıftan 46, dördüncü sınıftan ise 40 öğrenci olmak üzere toplam 86 öğrenci araştırmamıza katılmışlardır. Araştırma grubunda yer alan kız öğrenci sayıs1 48, erkek öğrenci sayısı ise 38 olarak sınırlandırılmıştır. Tarih öğretmeni adayları birinci ve ikinci öğretimden rastgele seçilmişlerdir.

\section{Sayıltılar}

Araştırma grubunda yer alan tarih öğretmeni adayları, kendilerine sorulan sorulara doğru bir şekilde yanıtlar vermişlerdir.

\section{Sinırlilıklar}

2020 -2021 Eğitim -Öğretim Y1lı Bahar Dönemi’nde, Gümüşhane Üniversitesi, Edebiyat Fakültesi, Tarih Bölümü’nde öğrenim gören 86 tarih öğretmeni adayları ile sinırlıdır.

\section{Verilerin Toplanmas1}

Tarih öğretmeni adaylarının sözlü iletişim becerilerini tespit etmek amaciyla (Maden, 2010) tarafindan geliştirilen "Sözlü İletişim Yeterlikleri Gözlem Formu (SIYGGF)" uygulanmıştır. Bu formun tarih öğretmeni adaylarına uygulanması için formu hazırlayan S. Maden ile görüşülerek gerekli izin alınmıştır. 20 maddeden meydana gelen (SIYYGF) anketin ilk 11 maddesi sözlü iletişim becerilerine yönelik "Fiæiki Nitelikleri, son 9 madde ise "Bilissel Nitelikler" belirlemek amaciyla kullanılmıştır. Anketteki her soru için şu puanlama yapılmıştır: Evet[3], Kısmen[2], Hayır[1]. SIYGF elde edilen bulgular, genel başarı düzeyi, cinsiyet ve sınıf değişkeni gibi hususlar dikkate alınarak değerlendirme yapılmıştır. Elde edilen veriler, SPSS 11.5 programı kullanılarak analiz edilmiştir.

\section{Araştırmanın Etik İzinleri}

Yapılan bu araştırmada 'Yükseköğretim Kurumları Bilimsel Araştırma ve Yayın Etiği Yönergesi” kapsamında yer alan bütün kurallara tamamen uyulmuştur. Yönergenin ikinci bölümü olan "Bilimsel Araştırma ve Yayın Etiğine Aykırı Eylemler" başlı̆̆ı altında belirtilen eylemlerden hiçbiri gerçekleştirilmemiştir.

Araştırmanın etik kurul onayını veren kurum: Gümüşhane Üniversitesi Bilimsel Araştırma ve Yayın Etik Kurulu.

Etik kurul onay tarihi:09.06.2021

Etik kurul onay sayısı: 2021/4 
Yapıcı, H. (2021). Tarih öğretmeni adaylarının sözlü iletişim becerileri üzerine bir araştırma,

Mavi Atlas, 9(2), 157-166

Bulgular ve Yorum

Tablo1. Tarih Öğretmeni Adaylarının Sözlü İletişim Becerilerine Yönelik Genel Ortalama Sonuçları (Fiziki Boyut)

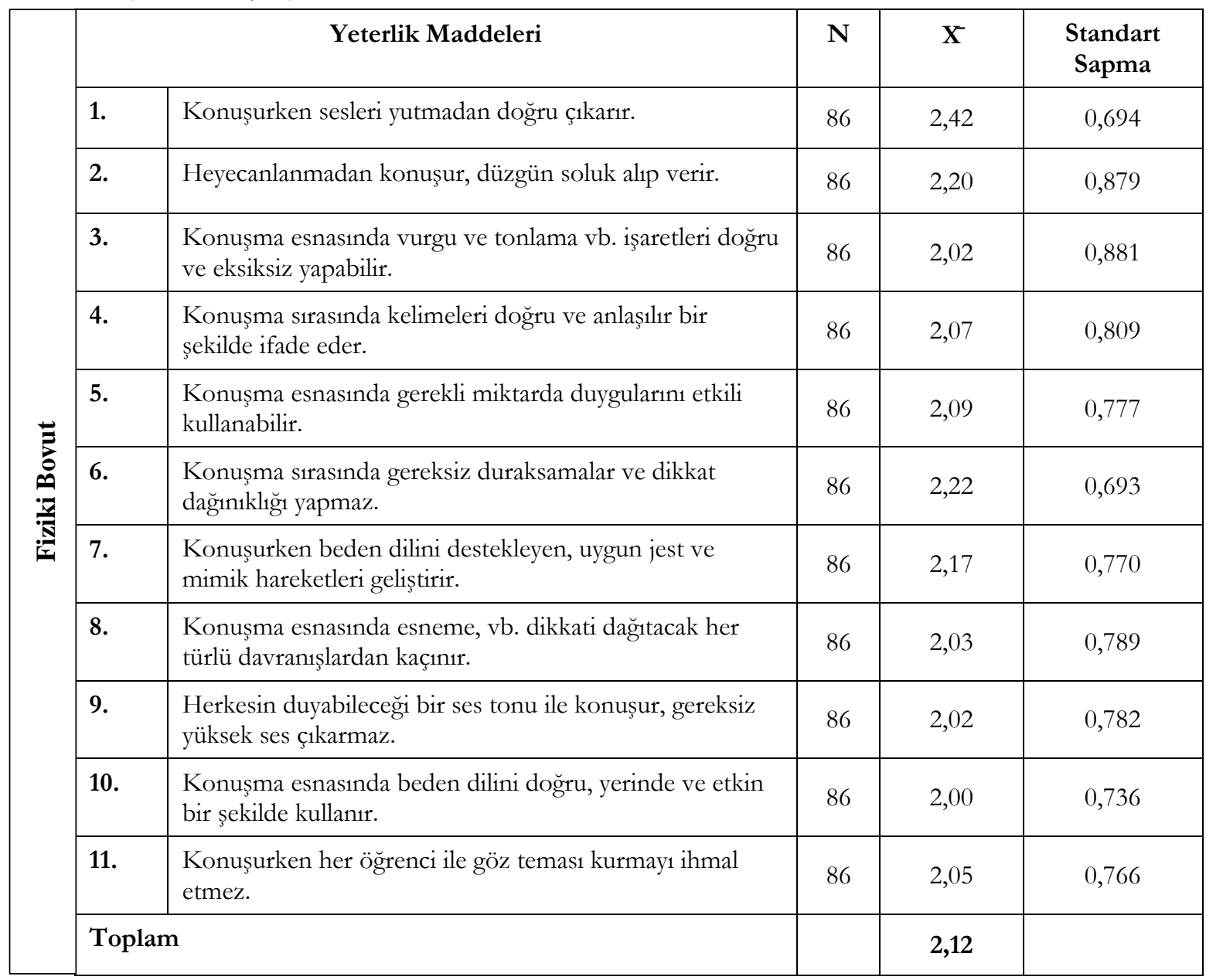

Yukarıdaki tabloda yer alan bulgulardan hareketle tarih öğretmeni adaylarının sözlü iletişim becerileri fiziki yap1 yönünden, "Konuşurken sesleri yutmadan doğru çıkarır." yeterliği için $X=2,42$; "Heyecanlanmadan konuşur, düzgün soluk alıp verir." yeterliği için $X=2,20$; "Konuşma esnasında vurgu ve tonlama vb. işaretleri doğru ve eksiksiz yapabilir." yeterliği için $\mathrm{X}=2,02$; "Konuşma sırasında kelimeleri doğru ve anlaşılır bir şekilde ifade eder." yeterliği için $\mathrm{X}=2,07$; "Konuşma esnasında gerekli miktarda duygularını etkili kullanabilir." yeterliği için $\mathrm{X}=2,09$; "Konuşma sırasında gereksiz duraksamalar ve dikkat dağınıklı̆̆1 yapmaz.." yeterliği için $\mathrm{X}=2$,22; "Konuşurken beden dilini destekleyen, uygun jest ve mimik hareketleri geliştirir." yeterliği için $\mathrm{X}=2,17$; "Konuşma esnasında esneme, vb. dikkati dağıtacak her türlü davranışlardan kaçınır." yeterliği için $\mathrm{X}=2,03$; "Herkesin duyabileceği bir ses tonu ile konuşur, gereksiz yüksek ses çıkarmaz." yeterliği için $\mathrm{X}=2,02$; "Konuşma esnasında beden dilini doğru, yerinde ve etkin bir şekilde kullanır. "yeterliği için $\mathrm{X}=2,00$; "Konuşurken her öğrenci ile göz teması kurmayı ihmal etmez." yeterliği için $\mathrm{X}=2,05$ oranında bir sözlü iletişim yeterliğine sahip oldukları belirlenmiştir. Ayrıca yine yukarıdaki tablo dikkate alındığında sözlü iletişim becerilerinin fiziki yapısına göre genel ortalama sonucu da sözlü iletişim yeterlikleri fiziki boyutuna yönelik genel ortalamalarının $\mathrm{X}=2,12$ olarak hesaplanmıştır. 
Yapıcı, H. (2021). Tarih öğretmeni adaylarının sözlü iletişim becerileri üzerine bir araştırma,

Mavi Atlas, 9(2), 157-166

Tablo2. Tarih Öğretmeni Adaylarının Sözlü İletişim Becerilerine Yönelik Genel Ortalama Sonuçları (Bilişsel Boyut)

\begin{tabular}{|c|c|c|c|c|c|}
\hline \multirow{11}{*}{ 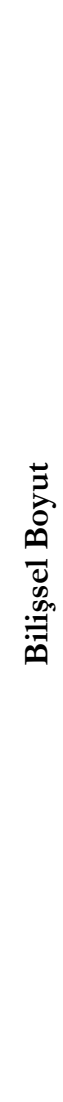 } & \multicolumn{2}{|r|}{ Yeterlik Maddeleri } & \multirow{2}{*}{$\begin{array}{l}\mathbf{N} \\
86\end{array}$} & \multirow{2}{*}{$\begin{array}{r}\mathbf{X} \\
2,05\end{array}$} & \multirow{2}{*}{$\begin{array}{c}\begin{array}{c}\text { Standart } \\
\text { Sapma }\end{array} \\
0,718\end{array}$} \\
\hline & 12. & $\begin{array}{l}\text { Konuşurken kullanacağı tümceleri doğru seçer, ana } \\
\text { temadan sapmadan etkili kullanmayı bilir. }\end{array}$ & & & \\
\hline & 13. & $\begin{array}{l}\text { Cümleleri çok uzun tutmaz, tümceler arasındaki } \\
\text { geçişi etkili ve doğru yapar. }\end{array}$ & 86 & 2,16 & 0,749 \\
\hline & 14. & $\begin{array}{l}\text { Konuşma sırasında anlatımı bozacak çelişkili, } \\
\text { müphem, karışık ifadeleri kullanmaktan kaçınır. }\end{array}$ & 86 & 2,10 & 0,703 \\
\hline & 15. & $\begin{array}{l}\text { Cümle içerisinde, yabancı kelime ve deyimleri } \\
\text { kullanmaz, günlük yaygın kullanılan sözcükleri seçer. }\end{array}$ & 86 & 2,02 & 0,735 \\
\hline & 16. & $\begin{array}{l}\text { Konuşurken cümleleri gereksiz ve sıkıcı sözcüklerle } \\
\text { uzatmaz. }\end{array}$ & 86 & 2,20 & 0,733 \\
\hline & 17. & $\begin{array}{l}\text { Konuşma esnasında konu akışını bozacak gereksiz } \\
\text { tekrarlara düşmemeye özen gösterir. }\end{array}$ & 86 & 2,10 & 0,669 \\
\hline & 18. & $\begin{array}{l}\text { Konuşurken herkesin anlayacağı bir dil kullanmaya } \\
\text { özen gösterir, ayrıca faklı yörelere ait şive ve ağız } \\
\text { özelliklerini, argo ifadeleri kullanmaktan sakınır. }\end{array}$ & 86 & 1,87 & 0,823 \\
\hline & 19. & $\begin{array}{l}\text { Konuşma sırasında iletişimi olumsuz etkileyecek } \\
\text { ayrıntıları kullanmaktan sakınır. }\end{array}$ & 86 & 2,06 & 0,787 \\
\hline & 20. & $\begin{array}{l}\text { Konunun daha iyi anlaşılabilmesi için günlük } \\
\text { hayattan uygun örnekler seçer. }\end{array}$ & 86 & 2,28 & 0,777 \\
\hline & \multicolumn{2}{|c|}{ Toplam } & & 2,09 & \\
\hline
\end{tabular}

Tarih öğretmeni adaylarının sözlü iletişim becerilerine ait bilişsel boyut kısmına ait maddelere verilen cevaplar analiz edildiğinde şu sonuçlarla karşılaşmaktayı: "Konuşurken kullanacağ1 tümceleri doğru seçer, ana temadan sapmadan etkili kullanmayı bilir." yeterliği için $\mathrm{X}=2,05$; "Cümleleri çok uzun tutmaz, tümceler arasındaki geçişi etkili ve doğru yapar.." yeterliği için $\mathrm{X}=2,16$; "Konuşma sırasında anlatımı bozacak çelişkili, müphem, karışık ifadeleri kullanmaktan kaçınır." yeterliği için $\mathrm{X}=2,10$; "Cümle içerisinde, yabancı kelime ve deyimleri kullanmaz, günlük yaygın kullanılan sözcükleri seçer." yeterliği için $\mathrm{X}=2,02$; "Konuşurken cümleleri gereksiz ve sıkıcı sözcüklerle uzatmaz." yeterliği için $X=2,20$; "Konuşma esnasında konu akışını bozacak gereksiz tekrarlara düşmemeye özen gösterir." yeterliği için $X=2,10$; "Konuşurken herkesin anlayacağı bir dil kullanmaya özen gösterir, ayrıca faklı yörelere ait şive ve ağız özelliklerini, argo ifadeleri kullanmaktan sakınır." yeterliği için $\mathrm{X}=1,87$; "Konuşma sırasında iletişimi olumsuz etkileyecek ayrıntıları kullanmaktan sakınır." yeterliği için $\mathrm{X}=2,06$ "Konunun daha iyi anlaşılabilmesi için günlük hayattan uygun örnekler seçer. " yeterliği için $\mathrm{X}=2,28$ sonucu öğretmen adayların sözlü iletişim noktasında bulunduğu seviyeyi göstermesi açısından dikkate değerdir. Yine tabloda yer alan sonuçlardan anlaşılacağı üzere genel ortalamalarının $\mathrm{X}=2,09$ olarak hesaplanmışır

Sonuç olarak istatistik analizlerden elde edilen sayısal veriler göstermektedir ki tarih öğretmeni adaylarının sözlü iletişim düzeyleri, alt boyutları genel olarak ortalamanın üstünde birbirine yakın değerler olarak karşımızda durmaktadır. Bu sonuçlar 1şığında tarih öğretmeni adaylarının meslek hayatlarında başarılı olabilmeleri için etkili iletişim becerileri kazanmaları önerilmelidir. 
Yapıcı, H. (2021). Tarih öğretmeni adaylarının sözlü iletişim becerileri üzerine bir araştırma,

Mavi Atlas, 9(2), 157-166

Tablo3. Tarih Öğretmeni Adaylarının Sözlü İletişim Yeterliklerinin Cinsiyet Değişkenine Göre Değerlendirilmesi

\begin{tabular}{|l|c|c|c|c|c|}
\hline Cinsiyet & N & $\mathbf{X}$ & Standart Sapma & $\mathbf{T}$ & P* \\
\hline Erkek & 38 & 1,963 & 0,254 & & \\
\cline { 1 - 3 } Kadin & 48 & 2,222 & 0,207 & $\mathbf{- 5 , 1 9 5}$ & $\mathbf{0 , 0 0 0}$ \\
\hline
\end{tabular}

*P. 0,05

Tabloda yer alan sonuçlar göstermektedir ki tarih öğretmeni adaylarının sözlü iletişim düzeylerinin cinsiyet faktörü dikkate alındığında kız öğretmen adaylarının X=1,963, aynı sonuçlar erkek adaylar için $\mathrm{X}=2,222$ olduğu tespit edilmiştir. Bu oranlar analiz edildiğinde bayan tarih öğretmeni adaylarının bay tarih öğretmen adaylara göre sözlü iletişim düzeylerinin daha yüksek olduğu görülmektedir. (t: -5,195; $\mathrm{p}<0,05)$.

Tablo4. Tarih Öğretmeni Adaylarının Sözlü İletişim Yeterliklerinin Sınıf Değişkenine Göre Değerlendirilmesi

\begin{tabular}{|l|c|c|c|c|c|}
\hline Cinsiyet & $\mathbf{N}$ & $\mathbf{X}$ & Standart Sapma & $\mathbf{T}$ & P \\
\hline 2. Sınıf & 46 & 1,913 & 0,175 & \multirow{2}{*}{$-12,247$} & 0,000 \\
\hline 4. Sinıf & 40 & 2,331 & 0,136 & \\
\hline
\end{tabular}

Tabloda elde edilen veriler 1şı̆̆ında şu sonuçları görmekteyiz: 2. sınıfta okuyan tarih öğretmeni adaylarının sözlü iletişim yeterliliğine sahiplik oranı $X=1,913$ iken bu oran 4. sınıfta $\mathrm{X}=2,331$ seviyesine yükselmiştir. $\mathrm{Bu}$ veriler sınıf durumu değişkenine göre sözlü iletişim becerilerinin 4. sınıfta okuyan tarih öğretmeni adaylarının lehine anlamlı bir farklılık içerdiğini ortaya koymaktadır. (t: $-12,247 ; \mathrm{p}<0,05)$.

\section{Sonuç}

$\mathrm{Bu}$ araştırmamızda tarih öğretmeni adaylarının sözlü iletişim düzeylerinin okuduğu sınıf, cinsiyet durumuna göre yeterlilikleri tespit edilmeye çalışılmıştır. Yapılan çalışmanın neticesinde tarih öğretmeni adaylarının fiziki alanda yer alan 11 soruya verilen yanıtları yeterlilik seviyesinin genel ortalamasının $\mathrm{X}=2,12$, bilişsel yapıdaki kalan son 9 soruya verilen yanıtlar yeterlilik düzeylerinin $X=2,09$ olduğu belirlenmiştir. Bu verilerden hareketle sözlü iletişim konusunda tarih öğretmeni adaylarının yeterlilik seviyeleri genel ortalamanın üzerindedir. Yine araştırma sonuçları 1şı̆̆ıında cinsiyet durumu değişkenine göre kadın tarih öğretmeni adaylarının sözlü iletişim becerisi yönünden erkek öğretmen adaylarına kıyasla daha başarılı oldukları görülmüştür. $(-5,195, \mathrm{p}<0,05)$. Diğer bir değişken olarak okuduğu sınıf durumu değişkeni dikkate alındığında 4. sınıf tarih öğretmeni adaylarının sözlü iletişim yeterliliğine sahip olma noktasında daha iyi bir seviyede oldukları anlaşılmıştır (t: $-12,247 ; \mathrm{p}<0,05)$.

Tarih öğretmeni adaylarının sözlü iletişim noktasında yeterli bir düzeyde oldukları öğrencilerle güvenilir ve sağlıklı iletişim kurabilecekleri elde edilen verilerden anlaşılmaktadır. Ayrıca elde edilen sonuçlar 1şığında 2. Sınıf tarih öğretmeni adaylarının sözlü iletişim kurmada son sınıf tarih öğretmeni adaylarına göre daha zayıf bir durumda oldukları, bunun sebebinin ise öğretmenlik uygulamalarına dâhil edilmemeleri kabul edilebilir. 
Yapıcı, H. (2021). Tarih öğretmeni adaylarının sözlü iletişim becerileri üzerine bir araştırma,

Mavi Atlas, 9(2), 157-166

Netice itibariyle tarih öğretmeni adaylarının sözlü iletişim alanında daha etkin ve başarılı olabilmeleri için farklı yöntemler geliştirilebilir. Öğretmenlik mesleğine yönelik okullardaki uygulama derslerine daha fazla ağırlık verilerek adayların öğrencilerle iletişimde becerileri gelişerek kendilerine olan öz güvenleri artırılabilir. Unutulmamalıdır ki öğretmenlik mesleği kutsal bir meslektir. Öğretmenler sosyal hayatta her zaman sözü dinlenen, fikirlerine ve düşüncelerine değer verilen kanaat önderleridir. Bu yüzden öğretmen adaylarının sözlü iletişim ve etkileşimde kendilerini çok iyi geliştirmeleri iyi diyalog kurabilecek becerileri kazanmaları gerekmektedir.

\section{Kaynakça}

Baki, E. (2019). Gençlerin spora kathlim düzeylerine göre iletişim becerileriyle problem şözme yeteneklerinin incelenmesi (Erzurum ili örneği) (Tez No. 566085) [Yüksek lisans tezi, Erzincan Binali Yıldırım Üniversitesi]. YÖK Ulusal Tez Merkezi.

Calp, M. (2005). Özel öğretim alan olarak Türkşe ögrretimi. Eğitim Kitabevi.

Demirel, Ö. (2001). Kuramdan uygulamaya eğitimde program gelisțtirme. Pegema Yayınc1lık.

Engin, A. \& Aydın, S. (2010). Sınıf içi iletişimde öğretmenin rolü. Atatürk Üniversitesi Kazım Karabekir Eg̈itim Fakültesi Dergisi, 16, 1-14.

Erdem, A. R. (2016, 28-30 Nisan). Öğretmen adaylarmm sinf yönetimi becerilerinden "ögrenciyle iletişim kurma" ya iliskin yeterlikleri hakekındaki görüsleri. [Konferans sunumu]. V. Uluslararası Sosyal Bilgiler Eğitimi Sempozyumu, Denizli, Türkiye.

Eyüp, B. (2013). Üniversite ögrencilerinin konusma becerilerini kullanmaya yönelik tutumlar. Milli Eğitim Yayınları.

Fidan, M. \& Küçükali, R. (2014). İlköğretim kurumlarında yöneticilerin iletişim becerileri ve örgütsel değerler. Eğitim Bilimler Araștırma Dergisi, 4(1), 317-334.

Habac1, İ., Ürker, A., Bulut, S., Atıc1, R. \& Habac1, Z. (2013). Beden dilinin eğitim $\begin{array}{lllll}\text { öğretim üzerine } \quad \text { etkileri. } & \text { Turkish } & \text { Studies, } & \text { (9), } & \text { 1639-1655. }\end{array}$ http://dx.doi.org/10.7827/TurkishStudies.5000

Karadăg, E. \& Çalıskan, N. (2009). Interaction and communication in the process of education and shared common area in the classroom. College Student Journal, 43(1), 123-128.

Küçüksüleymanoğlu, R. \& Çetinkaya, E. (2014). Meslek Lisesi öğretmenlerinin iletişimsel yeterlik düzeyleri (Vak'a İncelemesi- Yıldırım Ticaret Meslek Lisesi-), Adryaman Üniversitesi Sosyal Bilimler Enstitiisü Dergisi, 7(16), 327-365.

Maden, S. (2010). Türkçe öğretmeni adaylarının sözlü iletişim becerileri üzerine bir araştırma. Ekev Akademi Dergisi, 14(44), 145-154.

Saraç, C. (2006). Sözlü iletişim becerileri açısından Türk dili ve edebiyatı eğitimi, Millı Ë̈itim Dergisi, 169, 106-118.

Sever, S. (1998). Dil ve iletişim, Ankara Üniversitesi Eğitim Bilimleri Fakültesi Dergisi, 31, 5166.

Ocak, G. \& Karakuş, G. (2015). Öğretmen adaylarının tartışma becerilerine yönelik tutumları. Trakya Üniversitesi Sosyal Bilimler Dergisi, 20(1), 299-317.

Temizyürek, F., Erdem, İ. \& Temizkan, M. (2007). Konuşma eğitimi, Öncü Kitap Yayınevi.

Yılmaz, İ., Yoncalık, O. \& Çimen, Z. (2010). İletişim becerisi ile öğretimde yeterlik arasındaki ilişkinin öğrenci algılarına göre değerlendirilmesi. (Beden eğitimi ve spor alanı). Spormetre Beden Eğitimi ve Spor Bilimleri Dergisi, 8(4) 143-150. 
Yapıc1, H. (2021). Tarih öğretmeni adaylarının sözlü iletişim becerileri üzerine bir araştırma, Mavi Atlas, 9(2), 157-166

Ek:

\section{Etik Kurul Onayı Belgesi}

\section{T.C. GÜMÜŞHANE ÜNIVERSITESI Rektörlüğ̈i}

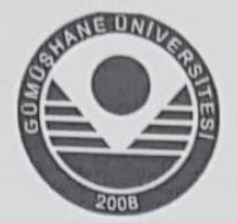

GÜMÜȘHANE

UNIVERSITY

Rector's Office

GÜMÜŞHANE ÜNIVERSITESI BiLIMSEL ARAŞTIRMA VE YAYIN ETIĞi KURULU

(Proje Onay Formu)

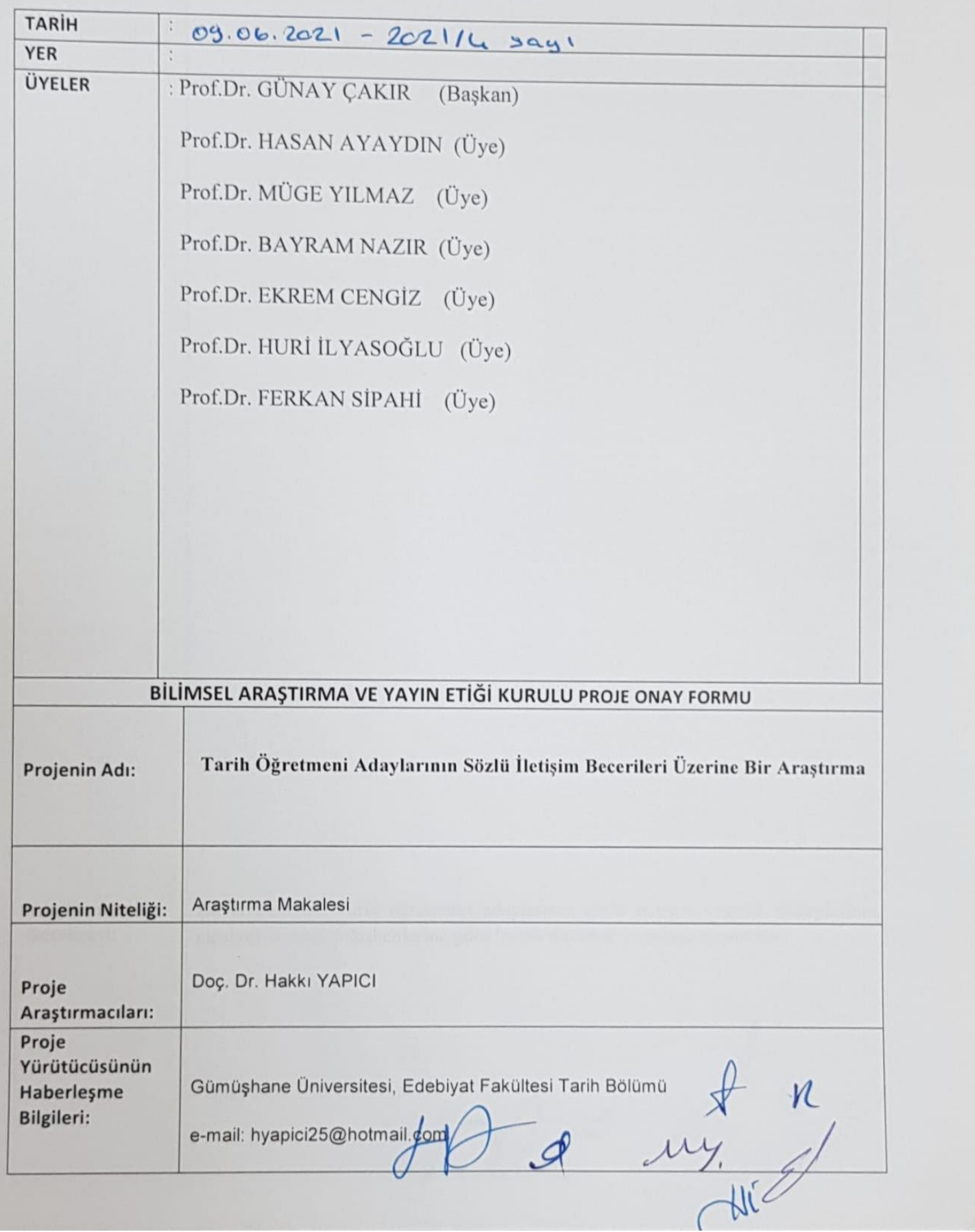


Yapıc1, H. (2021). Tarih öğretmeni adaylarının sözlü iletişim becerileri üzerine bir araştırma,

Mavi Atlas, 9(2), 157-166

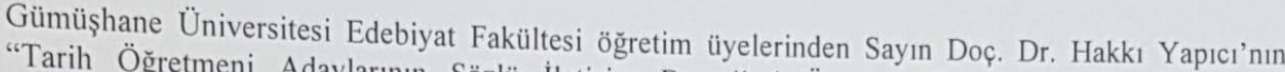
"Tarih Oğretmeni Adaylarının Sözlü İletişim Becerileri Üzerine Bir Araştırma" adlı projesi
değerlendirilmiştir.

Proje etik açısında uygun bulunmuştur.

Projenin etik açısından geliştirilmesi gerekmektedir.

Proje etik açısında uygun bulunmamıştır.

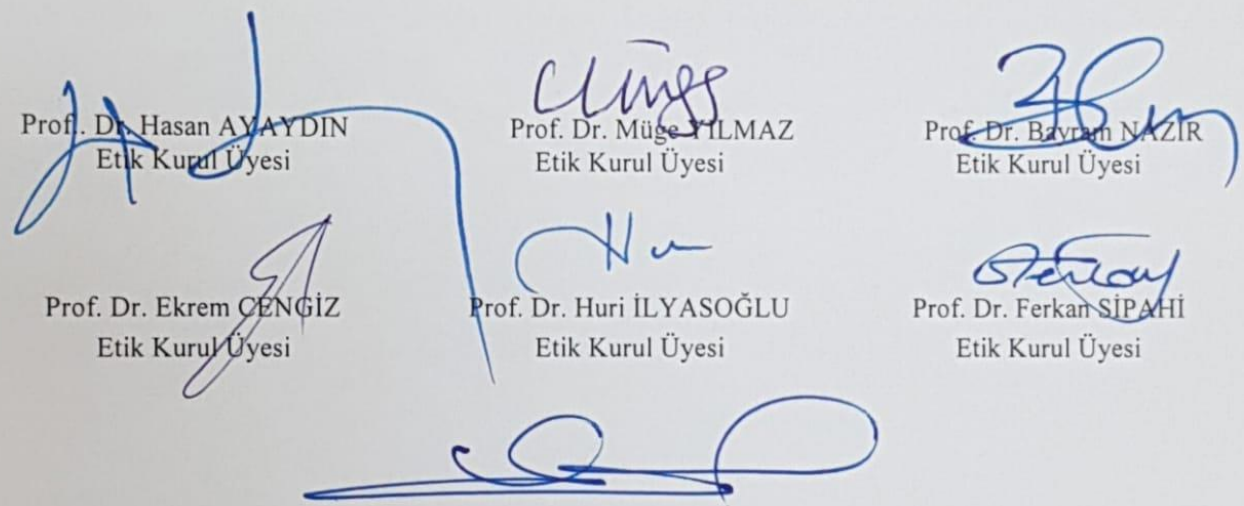

Prof. Dr. Günay ÇAKIR

Etik Kurul Başkanı 